\title{
Structural features and hydro-mechanical behaviour of a compacted andesitic volcanic soil
}

\author{
O. HERNANDEZ*, M. P. CORDÃO NETO $†$ and B. CAICEDO†
}

\begin{abstract}
Soils derived from volcanic ash comprise $0 \cdot 84 \%$ of the soils worldwide and this proportion increases in countries located on the Andean mountains. These soils have very unusual properties due to the presence of clay minerals not found in sedimentary soils. Particularly, the hydromechanical and structural properties of volcanic soils undergo huge changes depending on the degree of pre-drying of the samples. Although the main characteristics of volcanic soils have been studied during the last 50 years, few works focused on the hydromechanical and structural behaviour of compacted volcanic soils, which forms the purpose of this study. The behaviour of volcanic soil was evaluated using mineralogical characterisation tests, thermogravimetric analysis, compressibility, direct shear, waterretention curves and distribution of pores in the structure. The results showed the high irreversibility of the characteristics of the soil depending on the changes in water content that the soil undergoes before compaction.
\end{abstract}

KEYWORDS: compaction; fabric/structure of soils; residual soils

ICE Publishing: all rights reserved

\section{NOTATION}

$C_{\mathrm{c}}$ coefficient of compressibility

$e_{0} \quad$ initial void ratio

$I_{\mathrm{vn}}$ normalised void index

\section{INTRODUCTION}

Soils derived from volcanic ash comprise $0 \cdot 84 \%$ of the soils worldwide (Leamy, 1984), and this proportion can reach $15 \%$ in the countries located on the Andean mountains. In these countries, volcanic soils cover areas of high demographic and economic growth; and have produced several geotechnical problems (Cerda et al., 1996; Terlien, 1997; Bommer et al., 2002; Lizcano et al., 2006; Betancur et al., 2013).

Volcanic soils have high porosity, high water-retention capacity and high content of organic matter (Wesley, 1973; Nanzyo et al., 1989; Broquen et al., 1995; Garcia, 2003; Colombo et al., 2014). However, the physical properties of these soils experience huge changes depending on the degree of dryness of the sample (Wesley, 1973, 2009; Arango, 1993; IGAC, 1996; Herrera, 2005; Betancur et al., 2013; Ferrari et al., 2013).

On the contrary, volcanic soils are useful in a compacted state for several engineering applications. However, few works have focused on the hydromechanical properties of compacted volcanic soils, and the practice of compaction relies on empirical rules. This research study evaluates the

Manuscript received 9 April 2018; first decision 29 June 2018; accepted 10 July 2018.

Published online at www.geotechniqueletters.com on 21 August 2018.

*Department of Exact Sciences and Technologies, Federal University of Western Bahia, Bahia, Brazil

(Orcid:0000-0003-4344-0914).

†Department of Civil Engineering and Environment, Geotechnical Post-Graduation Program, University of Brasilia, Brasilia, Brazil.

tDepartment of Civil and Environmental Engineering, University of Los Andes, Bogotá, Colombia. effect of the different drying and wetting paths on the hydromechanical and structural features of compacted volcanic soils.

The results presented in this paper highlight the sensitive behaviour of volcanic soils leading to different practical recommendations for compaction depending on the type of work.

\section{MATERIALS AND METHODS}

Characterisation of the volcanic soil

Andesitic eruptions are the most common type of volcanic activity along the Andes mountain range. As described by Wesley (2014), soils derived from andesitic volcanic ashes contain very unusual clay minerals and amorphous materials such as allophanes resulting from the very rapid cooling, which inhibit the development of a crystalline structure in the fine molten particles. As shown in Fig. 1, allophanes are very tiny hollow spheres of around $5 \mathrm{~nm}$ in diameter, $3.8 \mathrm{~nm}$ in internal diameter and holes of around $0.3 \mathrm{~nm}$ (Iyoda et al., 2012). Allophanes are interwoven with another clay mineral known as imogolite, which consists of fine threadlike fibres. On weathering, allophanes produce halloysite, which also has unusual properties. Further weathering transforms halloysites into kaolinite.

Volcanic ash for this study was collected near Popayán Colombia at $2 \mathrm{~m}$ depth. Some geotechnical properties of the soil in the natural state are: water content of $78 \%$, specific gravity 2.59 ; dry density $6.43 \mathrm{kN} / \mathrm{m}^{3}$; void ratio 2.95 ; degree of saturation $69 \%$ and organic matter $17 \cdot 3 \%$ (estimated based on the loss on ignition at $440^{\circ} \mathrm{C}$ ).

According to Wesley (1973), the position of allophane clays in the plasticity chart is unusual because the liquid limit covers a wide range of values and could be extraordinarily high, but they lie well below the A-line. As shown in Fig. 2, this characteristic is also valid for the volcanic ash of this study (produced by the Puracé volcano) and for the soil studied by Herrera (2005), which was derived from the Nevado del Ruiz volcano. On the contrary, for soils submitted to hygroscopic drying (at the laboratory temperature of $24^{\circ} \mathrm{C}$ and relative humidity of $37 \%$ ) and 


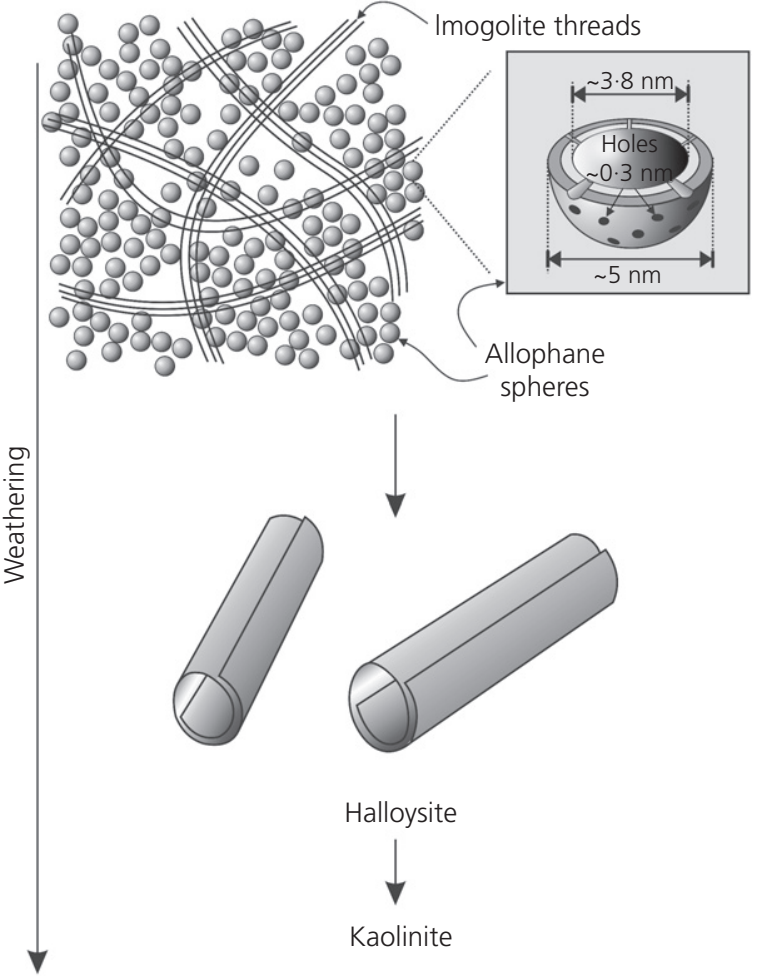

Fig. 1. Schematic drawing of allophanes and halloysites from lyoda et al. (2012)

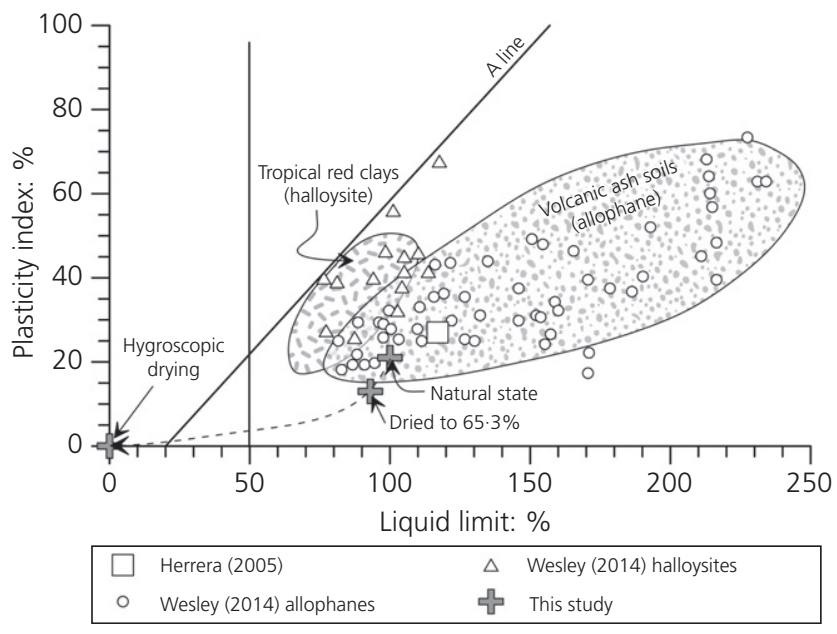

Fig. 2. Representation of tropical red clays and volcanic soils with allophanes in the plasticity chart results from Wesley (2014), Herrera (2005) and this study

re-saturation, the liquid limit and plasticity decrease transforming the soil from silt and clay into sandy soil. Similar results about the effect of drying on volcanic soils were reported by Wesley (1973), Herrera (2005) and Ferrari et al. (2013).

As shown in Fig. 3, drying also affects the grain-size distribution. Indeed, the natural soil sample has $62.5 \%$ of particles with sizes lower than $2 \mu \mathrm{m}$; this proportion decreases to $50 \cdot 8 \%$ when drying to $65 \cdot 3 \%$ of water content and $23 \cdot 1 \%$ for the hygroscopic-dried sample. These results show that on drying the sample form aggregation of particles producing larger grains.

The dehydration of allophanes and halloysites explains the differences in the liquid limit and plasticity index,

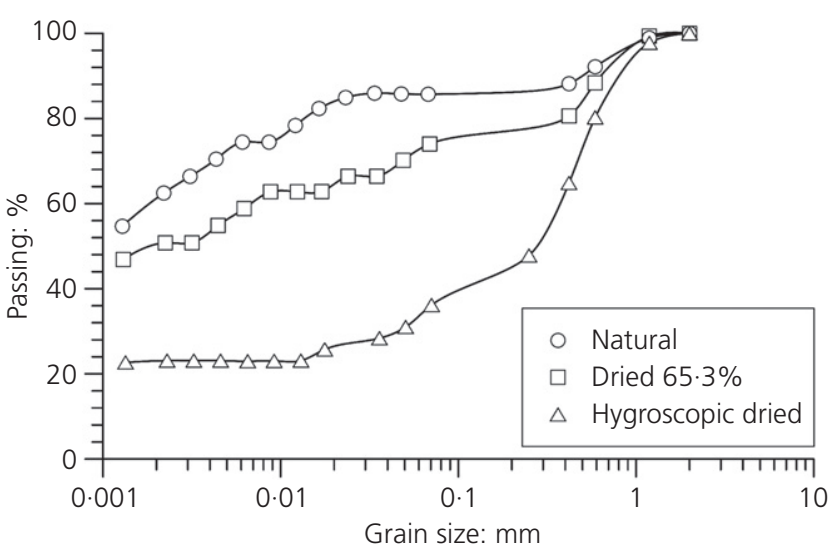

Fig. 3. Grain-size distributions of the natural sample, a sample dried to $65.3 \%$ of water content and a hygroscopic-dried sample

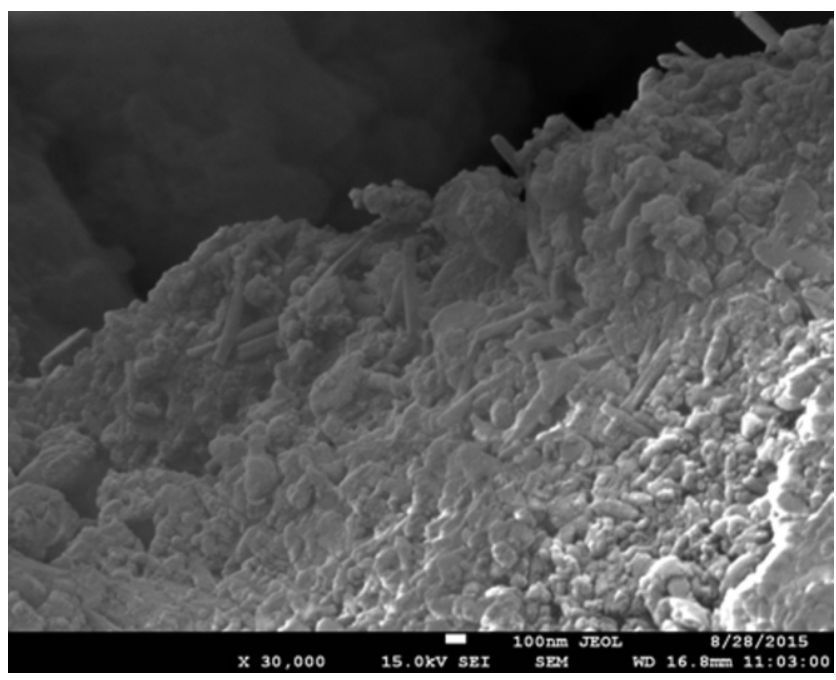

Fig. 4. Details of the halloysite in the form of tubes

as well as the change in the grain-size distribution, besides affecting the union between the particles (Wesley, 1973, 2009, 2014; Nanzyo et al., 1989; Tadashi \& Shoji, 2002).

The mineralogical analysis of the natural soil sample identified halloysite, gibbsite, quartz and cristobalite, while the dry sample had metahalloysite (halloysite dehydrated) and kaolinite. As well, the scanning electron microscope (SEM) observations, of a natural soil sample prepared using the clay separation and air-drying technique identified halloysite in the form of tubes (Fig. 4). The clay separation consists of the sedimentation of the material passing the \# 200 sieve during $12 \mathrm{~h}$, afterwards a small sample of the decanted material is observed. It is clear that this technique does not preserve the structure of the material.

\section{Compaction}

Two procedures were performed using the Standard Proctor. The first one consisted in drying the soil progressively from the natural water content and then compacted at different water contents; while in the second, the soil was dried to the hygroscopic water content and then wetted. Figure 5 and Table 1 show that hygroscopic drying lead to higher density, which confirms the influence of the drying process on compaction, an aspect already observed when analysing the soil's plasticity and grain-size distribution. 


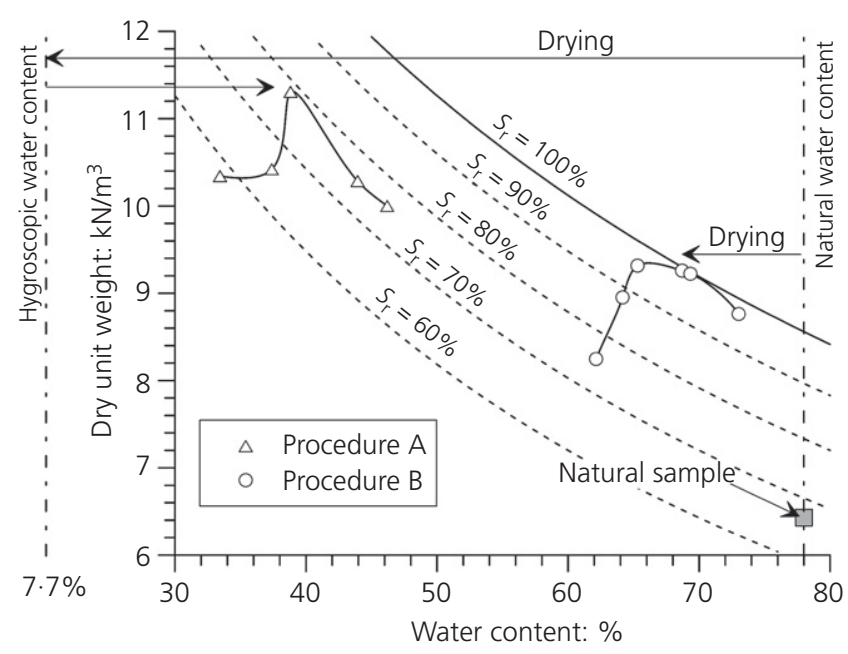

Fig. 5. Compaction curve using the Standard Proctor using two procedures of drying and wetting

Table 1. Properties of the optimum points of compaction

\begin{tabular}{l|c|c|c}
\hline Procedure & $\begin{array}{c}\text { Optimum } \\
\text { water } \\
\text { content: } \%\end{array}$ & $\begin{array}{c}\text { Dry unit } \\
\text { weight: } \\
\mathrm{kN} / \mathrm{m}^{3}\end{array}$ & $\begin{array}{l}\text { Void } \\
\text { ratio }\end{array}$ \\
\hline Hygroscopic drying + wetting & $38 \cdot 8$ & $11 \cdot 31$ & $1 \cdot 29$ \\
Progressive drying & $65 \cdot 3$ & $9 \cdot 32$ & $1 \cdot 77$ \\
\hline
\end{tabular}

The next section presents the study of the hydromechanical and structural features carried out for the samples natural and compacted at the optimum (denoted as $\mathrm{CH} 38.8$ for procedure A and CN65.3 for procedure B).

\section{HYDROMECHANICAL AND STRUCTURAL FEATURES \\ Structural features}

The structural features of the soil were evaluated combining different techniques: mercury intrusion porosimeter (MIP), nitrogen adsorption and SEM. To preserve the microstructure during dehydration, samples were frozen with liquid nitrogen $\left(-195^{\circ} \mathrm{C}\right)$ and dried in a vacuum oven (Otalvaro et al., 2016).

The pore distribution shows two ranges (Fig. 6): the first one has a broad variety of pore sizes $(0.5-100 \mu \mathrm{m})$, while the second has a narrower variation $(0 \cdot 003-0.005 \mu \mathrm{m})$. The first range represents the space between particles,

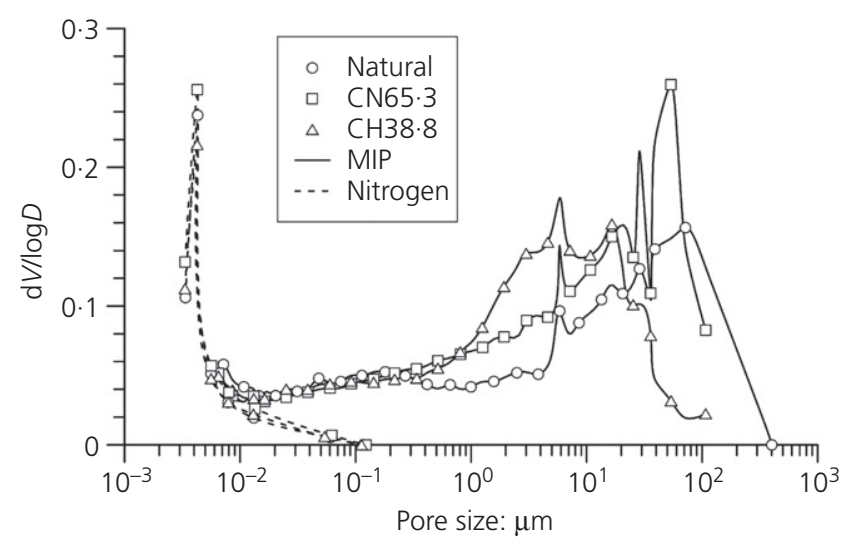

Fig. 6. Particle-size distribution curves obtained combining the techniques of MIP and nitrogen adsorption and the second is associated with the voids inside the tubes of halloysite.

The void ratio resulting from the volumetric analysis, and the void ratio measured in the MIP shows a discrepancy higher than $20 \%$. This difference indicates that mercury did not penetrate all the voids (Romero \& Simms, 2008), justifying the use of the nitrogen technique.

The microstructures of the natural samples CN65.3 and $\mathrm{CH} 38.8$ (Figs 7(a) and 7(b)) were evaluated qualitatively to verify the existence of halloysite in tubular form and the presence of pores and particles smaller than $1 \mu \mathrm{m}$. Figure 7(b) shows aggregations between particles and a more compact structure than Fig. 7(a), which could result from the dehydration of halloysite.

\section{Water-retention behaviour}

Figure 8 shows the water-retention curves (WRCs) measured along drying and wetting paths combining three methods. The suction plate for suctions was between 1 and $17 \mathrm{kPa}$ (Otálvaro, 2013); the axis translation technique for suctions was between 50 and $300 \mathrm{kPa}$ (Soto, 2004; Delage \& Cui, 2008; Otálvaro, 2013) and the chilled mirror apparatus WP4C for suctions was between 300 and $300000 \mathrm{kPa}$ (Cardoso et al., 2007; DDI, 2010).

All the drying curves seem to converge at high suctions for water contents close to $20 \%$ indicating that at this level of suction, the water remains within the micropores. For sample
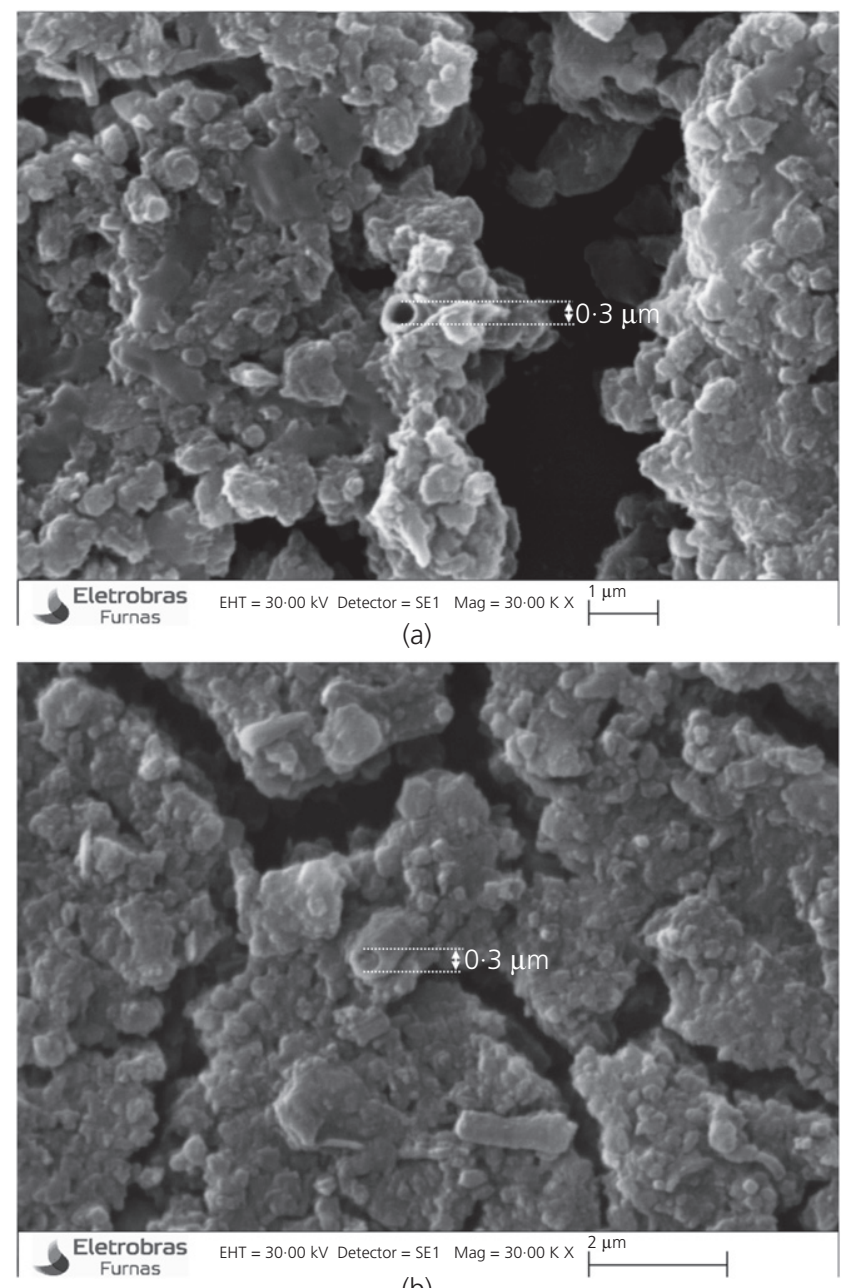

(b)

Fig. 7. (a) SEM of the natural sample, $30000 \times$ magnification; (b) SEM of sample $\mathrm{CH} 38 \cdot 8,30000 \times$ magnification 


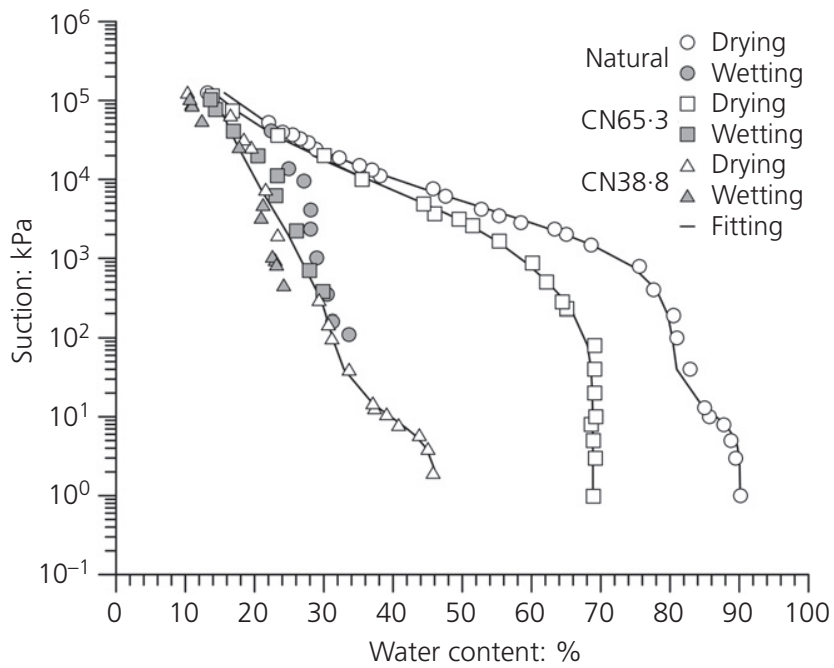

Fig. 8. WRCs with drying and wetting paths

CN65.3 and the natural sample, the shape of the curves is unimodal, and the drying and wetting paths show large hysteresis. On the contrary, sample $\mathrm{CH} 38.8$ showed few hystereses and lower water storage capacity. It is important to remark that the drying path of sample $\mathrm{CH} 38.8$ coincides with the wetting path of sample CN65.3 and the natural sample.

The adjustment of the curves for the drying trajectory was performed using the equation proposed by Durner (1994).

\section{Mechanical behaviour}

Changes in soil structure due to drying, observed in the porosimetry tests and the WRCs, influence the mechanical behaviour. Indeed, as shown in Fig. 9, drying reduces the voids between aggregates decreasing the initial void ratio and modifying the compressibility in two ways: changing the slope of the curves in the normally consolidated domain and their position in the $e-\sigma_{\mathrm{v}}^{\prime}$ plot.

The model proposed by Burland (1990) permits to predict the position of the compression curve using the normalised void index $I_{\mathrm{vn}}$, which relates the void ratio $e_{100}$, corresponding to the void ratio on the oedometric curve at $\sigma_{\mathrm{v}}^{\prime}=100 \mathrm{kPa}$, and the coefficient of compressibility $C_{\mathrm{c}}$ as follows

$$
I_{\mathrm{vn}}=\frac{e-e_{100}}{C_{\mathrm{c}}}
$$

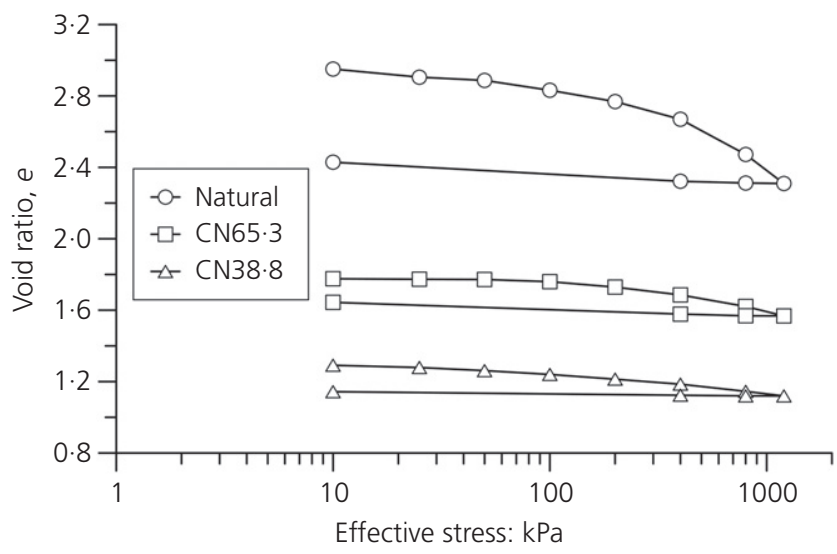

Fig. 9. Saturated compressibility curves of the natural and compacted materials

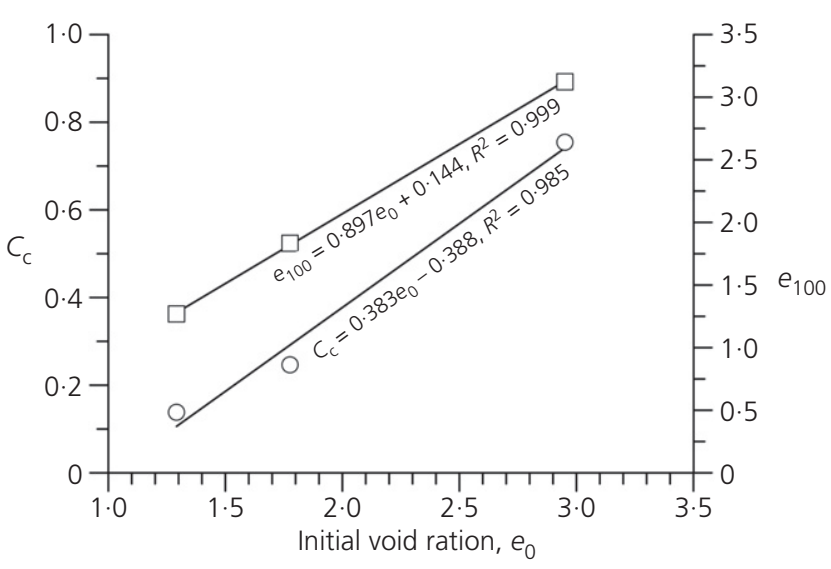

Fig. 10. Relationships between $e_{100}$ and $C_{c}$ and the initial void ratio $e_{0}$

The Burland model successfully describes the compressibility of reconstituted and natural normally consolidated clays (Hong et al., 2012; Shi \& Herle, 2015; Caicedo et al., 2018). For the compacted soils in this study, the two linear relationships shown in Fig. 10 relate well with the initial void ratio $e_{0}$ with the void ratio $e_{100}$ and the compressibility coefficient $C_{\mathrm{c}}$. These relationships are

$$
\begin{array}{ll}
e_{100}=0.897 e_{0}+0.144 & R^{2}=0.999 \\
C_{\mathrm{c}}=0.383 e_{0}-0.388 & R^{2}=0.985
\end{array}
$$

Figure 11(a) shows the results of the oedometric compression tests and the intrinsic compression line proposed by Burland (1990) in equation (6). As shown in Fig. 11(b), Burland's model that describes the compressibility of natural clays is also useful for describing the compressibility of compacted volcanic soils.

$$
I_{\mathrm{vn}}=2.45-1.285 \log \sigma_{\mathrm{v}}^{\prime}+0.015\left(\log \sigma_{\mathrm{v}}^{\prime}\right)^{3}
$$

Figure 12(a) represents the results of direct shear tests on saturated materials, shows that drying volcanic soils modify the shear strength drastically. Indeed, as shown in Fig. 12(b), the material in its natural state presents a significant effective cohesion, $c^{\prime}=25 \mathrm{kPa}$, resulting from a slightly cemented structure. This structure disappears when disaggregating the material before compaction, certainly, for the sample CN65.3, the effective cohesion decreases to $c^{\prime}=5 \mathrm{kPa}$. On the contrary, drying the material to its hygroscopic state increases the friction angle drastically from $\phi^{\prime}=27^{\circ}$ to $\phi^{\prime}=42^{\circ}$.

\section{DISCUSSION}

The results of this work show a strong link between the mineralogy and microstructure features with the water retention and mechanical behaviours. The following points summarise these links

- Drying the soil produce aggregation of particles and modifies the Atterberg limits, indicating a change in the mineralogy (changing halloysite to meta halloysite and dehydrating the allophanes).

- These changes explain the high hysteretic behaviour of the WRC for the samples natural and compacted at high water content, also explaining the slight hysteresis of the soil compacted in the dry state. As well, it is important to remark that after drying all wetting paths of the WRC 


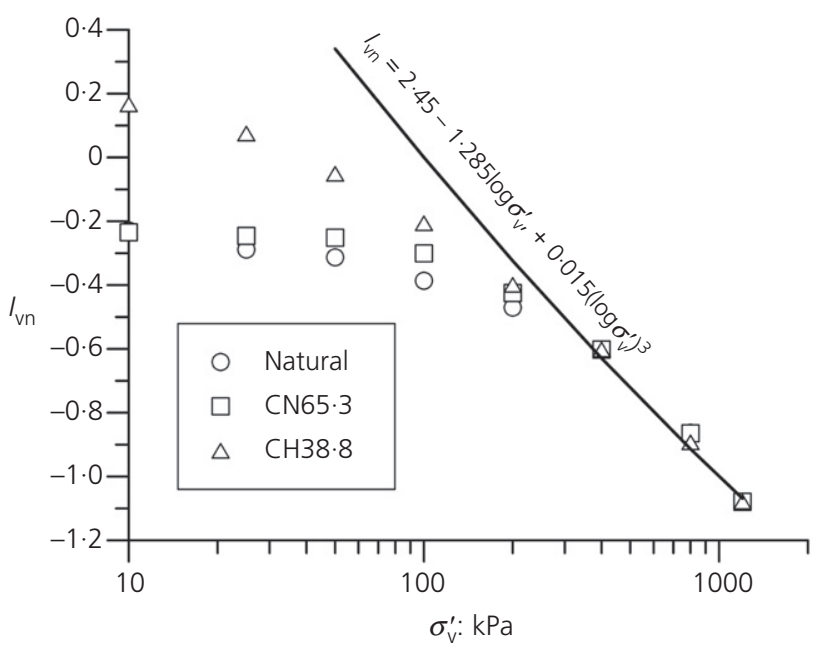

(a)

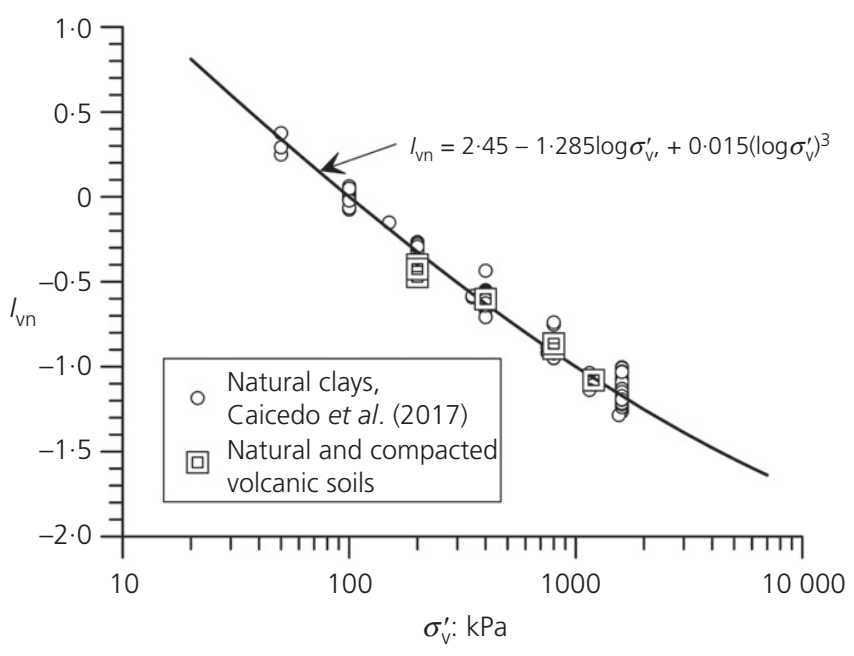

(b)

Fig. 11. Normalised compressibility curves: (a) volcanic soils in natural and compacted states; (b) post-yield results for natural clays and volcanic soils

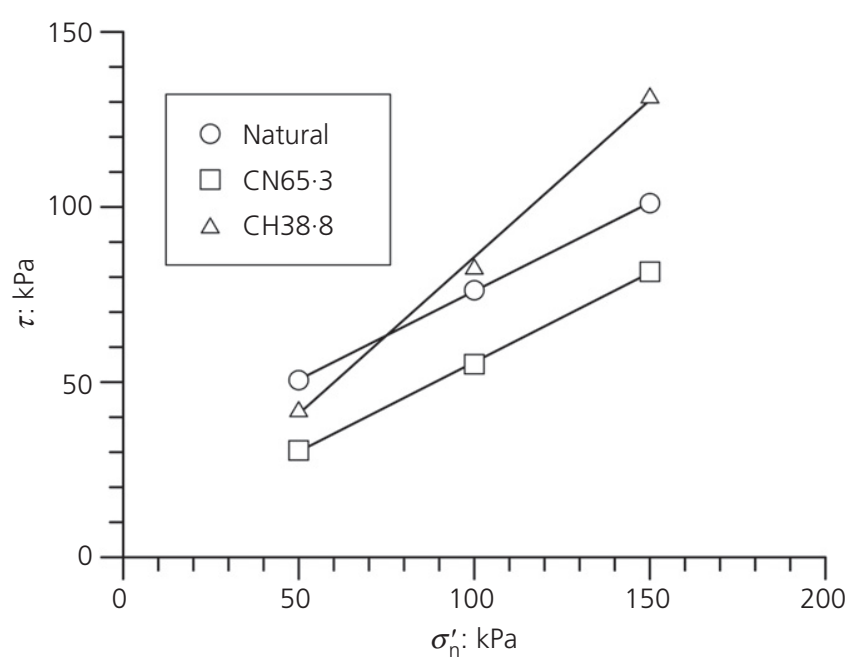

(a)

Fig. 12. Results of the shear strength tests on saturated samples

coincide, indicating that the changes in mineralogy and microstructure also occurs when drying the sample in the compacted or natural state.

- Regarding shear strength and compressibility, the changes in mineralogy and microstructure produce a significant increase in the friction angle and a reduction in compressibility, modifying the mechanical behaviour from clayey to sandy.

\section{CONCLUSIONS}

The usual framework of soil mechanics divides the physical properties in two: intrinsic and state properties. Intrinsic properties are constant and independent of the stress and hydraulic paths, whereas state properties depend on the soil's condition. The results presented in this study demonstrate that using this framework for compacted volcanic soils is awkward. Indeed, for these soils some properties that are usually considered as intrinsic vary when drying and are irreversible when wetting (i.e. Atterberg limits, grain-size distribution, coefficient of compressibility in the normally consolidated domain and friction angle). This study shows

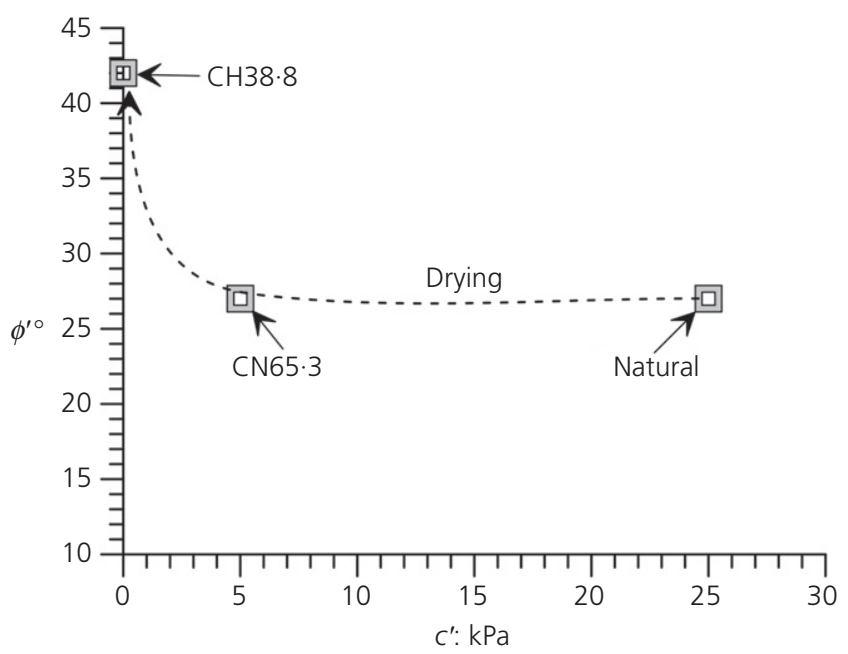

(b)

that the natural sample, and the sample dried progressively, have clayey and silty behaviour while it becomes a soil with sandy behaviour after hygroscopic drying. As well, state properties such as the WRCs and compressibility undergo huge changes after drying. This evolution of the intrinsic and state properties could be related to the dehydration of the halloysite and allophanes, which breaks the union between the aggregates that form the clay packs, thereby affecting the plasticity and decreasing the percentage of fine material in the soil.

Despite the huge changes that the soil undergoes on drying, models that permit describing sedimentary soils also are useful for describing compacted volcanic soils; this is the case of the Durner's model for describing the WRC and Burland's model for describing the normally consolidated behaviour.

The results presented in this paper suggest that practitioners must be cautious when considering the possibility of improving volcanic soils by compaction. Indeed, for some engineering applications, the natural soil could behave better than compacted soils. This difference in performance depends on stresses 
- In the case of shallow foundations of light structures applying low stresses $\left(\sigma_{\mathrm{v}}<75 \mathrm{kPa}\right.$ in Fig. 12(a)), the natural soil presents higher shear strength than compacted soil. Also, the natural material shows low compressibility because it is overconsolidated.

- Since the natural volcanic soil has lightweight and high shear strength, it can sustain vertical slopes without using retention structures.

- Compaction in the dry state produce the better geotechnical characteristics for engineering works mobilising high shear stresses (i.e. unpaved roads or high retaining walls).

- Compaction in the wet state does not improve the shear strength at any stress, but it produces some reduction in the compressibility.

\section{REFERENCES}

Betancur, Y., Builes, M. \& Millán, A. (2013). Variación de las propiedades mecánicas de arcillas alófanas en colombia al variar el grado de saturación. Rev. EIA 10, No. 20, 173-181 (in Spanish).

Bommer, J. J., Rolo, R., Mitroulia, A. \& Berdousis, P. (2002). Geotechnical properties and seismic slope stability of volcanic soils. 12th European conference on earthquake engineering, London, UK. Oxford, UK: Elsevier.

Broquen, P., Giardin, J. \& Frugoni, P. (1995). Evaluación de algunas propiedades de suelos derivados de cenizas volcánicas asociadas con forestaciones de coníferas exóticas (so de la provincia de neuquén - r. argentina). Bosque 16, No. 2, 69-79 (in Spanish).

Burland, J. B. (1990). On the compressibility and shear strength of natural clays. Géotechnique 40, No. 3, 329-378, https://doi.org/ 10.1680/geot.1990.40.3.329

Caicedo, B., Mendoza, C., López, F. \& Lizcano, A. (2018). Behavior of diatomaceous soil in lacustrine deposits of Bogotá, Colombia. J. Rock Mech. Geotech. Engng 10, No. 2, 367-379.

Cardoso, R., Romero, E., Lima, A. \& Ferrari, A. (2007). A comparative study of soil suction measurement using two different high-range psychrometers. In Experimental unsaturated soil mechanics, vol. 112, pp. 79-93. Berlin, Germany: Springer.

Cerda, A., Calvo, A., Lavee, H. \& Imeson, A. C. (1996). Erosionabilidad del suelo a lo largo del gradiente climático coll de rates. IV Reunión de Geomorfología, A Coruña, Spain (eds A. Grandal D’Anglade \& J. Pagés Carlos), pp. 695-707 (in Spanish). Zaragoza, Spain: Sociedad Española de Geomorfología.

Colombo, C., Sellitto, V. M., Palumbo, G., Di Iorio, E., Terribile, F. \& Schulze, D. G. (2014). Clay formation and pedogenetic processes in tephra-derived soils and buried soils from centralsouthern Apennines (Italy). Geoderma 213, 346-356.

DDI (Decagon Devices, Inc.) (2010). Dewpoint potentiameter. WP4C potenciameter. Operator's manual, version 2. Pullman, WA, USA: Decagon Devices, Inc.

Delage, P. \& Cui, Y. J. (2008). An evaluation of the osmotic method of controlling suction. Geomech. Geoeng. 3, No. 1, 1-11.
Durner, W. (1994). Hydraulic conductivity estimation for soils with heterogeneous pore structure. Water Resour. Res. 30, No. 2, 211-223.

Ferrari, A., Eichenberger, J. \& Laloui, L. (2013). Hydromechanical behaviour of a volcanic ash. Géotechnique 63, No. 16, 1433-1446.

Herrera, M. C. (2005). Suelos derivados de cenizas volcánicas en Colombia: Estudio fundamental e implicaciones en ingeniería. Tesis de doctorado, Departamento de Ingeniería Civil y Ambiental, Universidad de Los Andes, Bogotá, Colombia (in Spanish).

Hong, Z. S., Zeng, L. L., Cui, Y. J., Cai, Y. Q. \& Lin, C. (2012). Compression behaviour of natural and reconstituted clays. Géotechnique 62, No. 4, 291-301.

Iyoda, F., Hayashi, S., Arakawa, S., Okamoto, M., Hayashi, H. \& Yuam, G. (2012). Synthesis and adsorption characteristics of hollow spherical allophane nano-particles. Appl. Clay Sci. 56, 77-83.

Leamy, M. L. (1984). International committee on the classification of andisols (ICOMAND) circular newsletter no. 6. Lower Hutt, New Zealand: New Zealand Soil Bureau, DSIR.

Lizcano, A., Herrera, M. C. \& Santamarina, J. (2006). Suelos derivados de cenizas volcánicas en colombia. Rev. Int. Desastr. Nat. Accid. e Infraestruct. Civ. 6, No. 2, 167-198 (in Spanish).

Nanzyo, M., Shoji, S. \& Dahlgren, R. (1989). Physical characteristics of volcanic ash soils. Dev. Soil Sci. 21, 189-207.

Otálvaro, I. (2013). Comportamento hidromecânico de um solo tropical compactado. Tese de doutorado, Departamento de Engenharia Civil e Ambiental, Universidade de Brasília, Brasília, Brazil (in Portuguese).

Otalvaro, I. F., Neto, M. P. C., Delage, P. \& Caicedo, B. (2016) Relationship between soil structure and water retention properties in a residual compacted soil. Engng Geol. 205, $73-80$

Romero, E. \& Simms, P. H. (2008). Microstructure investigation in unsaturated soils: a review with special attention to the contribution of mercury intrusion porosimetry and environmental scanning electron microscopy. Geotech. Geol. Engng, 26, No. 6, $705-727$.

Shi, X. S. \& Herle, I. (2015). Compression and undrained shear strength of remoulded clay mixtures. Géotech. Lett. 5, No. 2, $62-67$

Soto, M. A. A. (2004). Comparação entre métodos de imposição e controle de sucção. Tese de doutorado, Escola de Engenharia de São Carlos, Universidade de São Paulo, São Carlos, Brazil (in Portuguese).

Tadashi, A. \& Shoji, S. (2002). Distribution and classification of volcanic ash soils. Glob. Environ. Res. Ed. 6, No. 2, 83-97.

Terlien, M. T. J. (1997). Hydrological landslide triggering in ash-covered slopes of Manizales (Colombia). Geomorphology 20, No. 1-2, 165-175.

Wesley, L. (1973). Some basic engineering properties of halloysite allophane clays in Java, Indonesia. Géotechnique 23, No. 4, 471-494.

Wesley, L. (2009). Behaviour and geotechnical properties of residual soils and allophane clays. Obras y Proy., 6, 5-10.

Wesley, L. D. (2014). Classification and characterisation of tropical residual soils. XIV Congreso Colombiano de Geotecnia, Bogotá, Colombia, pp. 1-15. Bogotá, Colombia: Sociedad Colombiana de Geotecnia.

\section{HOW CAN YOU CONTRIBUTE?}

To discuss this paper, please submit up to 500 words to the editor at journals@ice.org.uk. Your contribution will be forwarded to the author(s) for a reply and, if considered appropriate by the editorial board, it will be published as a discussion in a future issue of the journal. 